Ethiopian Journal of Environmental Studies \& Management 10(5): 572 - 587, 2017.

ISSN:1998-0507

doi: https://dx.doi.org/10.4314/ejesm.v10i5.2

Submitted: December 10, 2016

Accepted: June 05, 2017

\title{
REMOTE SENSING AND GIS APPLICATIONS IN DETERMINING SHORELINE AND SURFACE WATER QUALITY CHANGES IN BAYELSA STATE, NIGERIA
}

\author{
ADEBOLA, A.0., ${ }^{*}$ OGUNRIBIDO, T.H.T., ${ }^{2}$ ADEGBOYEGA, S.A., ${ }^{1}$ IBITOYE, M.0. $^{1}$ AND \\ ADESEKO, A.A. ${ }^{1}$ \\ ${ }^{1}$ Department of Remote Sensing and GIS, Federal University of Technology, Akure, Ondo \\ State \\ ${ }^{2}$ Department of Earth Sciences, Adekunle Ajasin University, Akungba-Akoko, Ondo State
}

\begin{abstract}
The study of shoreline changes is essential for updating the changes in shoreline maps and management of natural resources as the shoreline is one of the most important features on the earth's surface. Shorelines are the key element in coastal GIS that provide information on coastal landform dynamics. The purpose of this paper is to investigate shoreline changes in the study area and how it affects surface water quality using Landsat imagery from 1987 to 2016. The image processing techniques adopted involves supervised classification, object-based image analysis, shoreline extraction and image enhancement. The data obtained was analyzed and maps were generated and then integrated in a GIS environment. The results indicate that LULC changes in wetland areas increases rapidly during the years (1987-2016) from 34.83 to 38.96\%, vegetation cover reduces drastically through the year which range from $30 \%$ to $20 \%$. Polluted surface water was observed to have decreased from 30\% to 20\% during 1984-2010 and reduced by about 3\% in 2016. In addition, the result revealed the highest level of erosion from 1987 to 2016 which is $49.60 \%$ against the highest level of accretion of $13.39 \%$ EPR and NSM -1400 erosion against 350 accretions. It was also observed that variations in shoreline changes affect the quality of surface water possibly due to shoreline movement hinterland. This study has demonstrated that through satellite remote sensing and GIS techniques, the Nigerian coastline can adequately be monitored for various changes that have taken place over the years.
\end{abstract}

Key Words: Shoreline, Remote Sensing, Erosion, Accretion, GIS

\section{Introduction}

Shoreline is the interface between land and water and it is considered one of the most dynamic processes in the coastal area. Shoreline position is continuously changing through the time, because of the dynamic nature of the water level at coastal boundaries such as waves, tides, groundwater, storm surges, geomorphic processes of erosion, accretion and human activities (Boak and Turner, 2005; Bird, 2000). Remote-sensing data could be used effectively to observe the changes along the coastal zone,

*Corresponding Author: Ogunribido, T.H.T.

Email: ogunribido_henry@yahoo.com 
including shoreline with reasonable accuracy. Remote sensing helps to replace the conservative survey data by its rhythmic and cost effectiveness. The world's coastlines are dynamic and shorelines that are in equilibrium undergo advancement towards the sea or recession towards the land which is very often due to man's construction of structures as a part of different activities in coastal zone.

The erosion trend is expected to increase under the scenario of rising sea level as a result of climate change. However, the coastal zone is increasingly under pressure from human activities such as fishing, coral and sand mining, mangrove harvesting, and seaweed farming, sewage disposal, urban expansion and tourism. Coastal zone supports many different types of livelihood that are sometimes at odds with each other. Man's endeavors such as Fishing, tourism, manufacturing, farming, and other industries are all very important to the coastal areas, but without proper planning, damaging conflicts can emerge and that can destroy the very resources that support these economic activities. Coastlines are dynamic areas (Boak and Turner, 2005). As a result; the accurate mapping of the instantaneous coastline position has always been associated with significant uncertainty. It is also controlled by the actions of rip and long shore currents, which results in cross-shore and alongshore sediment movement respectively in the littoral zone. Consequently, this affects the accuracy of computed historic rates of change and therefore the reliability of any identified erosion 'hotspots'. However, the science of coastline mapping has changed in the past 70 years due to advances in technology hence, the need to reduce uncertainty. The changes in the coastline largely depend on its geology and geomorphology; the nature of tidal waves impacting the coastline; changes in sealevel; and sediment transport by longshore currents (Carter and Woodroffe, 1994; Cowell and Thorn, 1994; Pidwirny, 2006). Coastline changes often result in erosion of coastal areas or accretion off - sediments, depending on the dominant processes acting on the coastline (Pidwirny, 2006). Likewise, the human activities that impact coastlines include; dredging, construction of breakwater infrastructure and physical development, mineral exploration, ports construction, removal of backshore vegetation, construction of barrages and coastal control works (Fanos et al., 1995; Berger and Lams, 1996; Pandian et al., 2004). The coastline is the bridge between aquatic life and terrestrial life, and it is usually a fragile eco-zone. As a result, the study of coastline changes can be of immense benefit to the understanding of complex coastal ecosystems. In addition, coastlines are widely used as ports for navigation and maritime commerce. They are therefore of economic value and critical to the socio-economic development of non-land locked nations. Several methods have been employed to study and monitor coastlines, including traditional methods that incorporate local observations and basic surveying techniques. Analysis of coastline changes have also been carried out using survey maps (Kadib, 1969), historical coastline mapping (e.g. XYZ), and comparison of beach profiles over a period of time (Inman and Jenkins, 1984). Other more recent methods include simulation of coastline changes 
using numerical models (El-Serafy, 1984); combination of coastline survey using Global Positioning System (GPS) receivers; long-shore sediment transport using numerical modeling packages such as MIKE21 and LITPACK (Pandian et al., 2004); and airborne Light Detection and Ranging (LIDAR) survey methods ( Robertson et al., 2004). All these methods had been used with varying accuracy to determine the position of the coastline at specific time periods and to detect coastline changes over time. However, the use of satellite remote sensing techniques and geographic information systems (GIS) for the identification, mapping and analyses of coastline changes have gained prominence in recent years. As a result, high resolution satellite data have become more readily available. Previous works in this direction include Moore (2000), ElRaey et al. (1997) and El-Amsar (2002).

These studies showed that remote sensing techniques when combined with geomorphologic and sedimentary data can be effectively used to assess coastline changes over time. In Nigeria, there is dearth of information on accelerated marine processes along the national coastline with the notable exception of the works of Usoroh (1971), Ibe (1985), Ibe and Anita (1983), and Ebisemiju (1986). Most of these studies on the Nigerian Coastline have concentrated mainly on the mapping and origin of coastal landforms (Pugh, 1954; NEDECO, 1954; Webb, 1958, 1960; Allen, 1965; Areola, 1977; Oyegun,, 1991; Oyegoke, 1982). The portion of the study covering the Niger Delta coastline focused primarily on four major locations, namely; Escravos, Forcados, Brass coast and Ibeno Eket. However, the aim of this study is to examine the shoreline changes and to assess its effect on the water quality in the Bayelsa coastline.

\section{Study Area}

The study area is Bayelsa State and it lies between Latitudes $4.20^{\circ} \mathrm{N}$ and $5.00^{\circ}$ $\mathrm{N}$ of Equator and Longitudes $5.20^{\circ} \mathrm{E}$ and $6.40^{\circ} \mathrm{E}$ of Greenwich Meridian. The area is located in the core Niger Delta region at the Southern part of Nigeria (Figure1). Economically, Bayelsa State has one of the largest crude oil and natural gas deposits in Nigeria. As a result, petroleum production is extensive in the state. It has a riverine and estuarine setting. A lot of her communities are almost (and in some cases) completely surrounded by water, hence making these communities inaccessible by road. The other important cities besides Yenagoa include Akassa, [Lobia] and Amassoma. The state is within the Coastal alluvium, mangrove and fresh-water swamps hydrogeologic province. Coastal Plain Sands which constitute the regional aquifer is highly lenticular and contains irregular lenses of aquitard (Ekine and Osobonye, 1996). The topography is invariably gentle. Average elevation stands at about $50 \mathrm{~m}$ above sea level. The average rainfall in the area is about 1700 mm/annum (Ako, 1982), most of which occurs in the rainy season which ensures adequate recharge. There are a number of perennial streams and rivers in the area of survey. They all form a network which empties to the Atlantic Ocean. As a result, most of the terrain is marshy and in some cases form beaches.

The development of a delta is governed by the interactions of the processes of subsidence, deposition and erosion (Sullivan and Squire, 1980). 
These interactions create complex sequences of interbeded sands, silts, clays and organic rich sediments termed lithofacies. The sediments which form the delta also vary with distance from sediment source. The more proximal deposition zones, such as the shoreline, are dominated by tidal channel and coastal barrier sands overlaying earlier (Holocene) marine clays (NDES, 1999). The delta slope deposition zone, in water depths of approximately $15 \mathrm{~m}$, is characterized by marine sands. The local geology around the Akanfa is composed of sediments which are characteristic of several depositional environments. The area essentially reflects the influence of movements of rivers, in the Niger delta and their search for lines of flow to the sea with consequent deposition of transported sediments. The surface deposits in this area comprise silt and sandy-clays. The sandy layers underlying the silt and sandy clay are predominantly medium to coarse grain sizes and found to exist in mostly medium state of compaction.

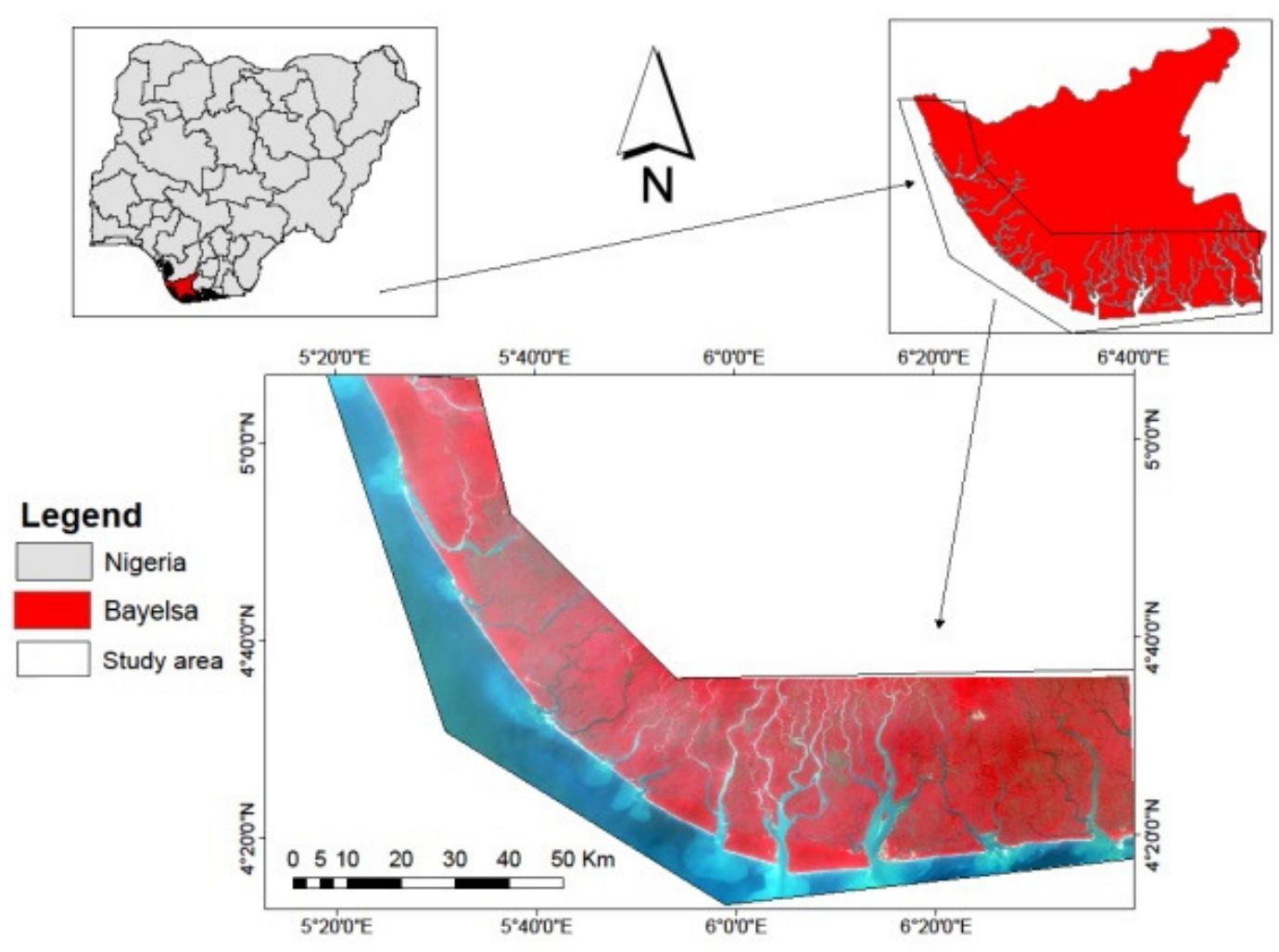

Fig. 1: Map showing the study area.

\section{Materials and Methods}

This study made use of satellite imageries of the study area. Landsat TM of $30 \mathrm{~m}$ by $30 \mathrm{~m}$ of $1987,1992,2010$ and 2016 were acquired from www.usgs.gov. The satellite imageries underwent series of geo-processing in order to make them 
suitable for further analysis. The bands (red, blue and green) of each image were combined using ArcGIS 10.2 and geo referenced to geographic coordinates of Universal Traverse Mercator (UTM) of Minna Datum (Zone 31N), using the same control points. Geo-referencing is important to prepare two or more satellite images for an accurate change detection comparison, it is imperative to geometrically rectify the imagery (Eludoyin et al., 2011). This made it possible for all the imageries to align and overlay perfectly. The images were later subjected to image enhancement, an image processing technique. This made it possible to obtain a sharp boundary between the land and ocean which served as the shoreline. Thereafter, the digitization of the shorelines in the images of each year was done in ArcGIS 10.2 as POLYLINES (Vector Data). The digitized shorelines of each year were subjected to spatial analyses.

\section{Image Processing}

The image processing for the project was carried out using ArcGIS 10.2. The acquired Landsat TM and ETM images scenes for this study were pre-processed, that is the radiometric and geometric corrections, and geo-referencing have been done. However, the coastlines boundaries were verified using existing vector maps for consistency and accuracy.

The band combination used for the images was: Red - band 6, Green - band 4 , and Blue - band 2. The reason for using the thermal band was for clear distinction of the coastline boundary (El-
Asmar, 2002). The different images (change detection analysis) were generated between the before images (Landsat TM) and the after images (Landsat ETM+). The software was programmed to detect the minimum level of change of $1 \%$. This means that an area identified to have changed for as low as $1 \%$ during the period of consideration should be duly highlighted. Visual analysis and comparison of the different images with the original images was used to identify areas of positive changes seawards (coastline accretion) represented in white (or green on the highlight image), and areas of negative changes coastline erosion) shown in black (or red on the highlight images). The areas of observed changes were extracted into a GIS database using ArcInfo 9.1.

\section{GIS Analysis}

The basic GIS operations carried out on the processed images are digital extraction of identified areas of changes along the coastline, digitization of the coastlines for the years of study and area calculation in order to know the size of changes (in $\mathrm{km}^{2}$ ). All GIS operations were carried out using ArcInfo 9.1.

\section{Results and Discussion}

The images generated during the period of study are presented as figures 2 to 5. The variations in the shoreline also affect the quality of surface water over time. As the shoreline moves hinterland, more surface water are polluted (Figures 2 to 5$)$. 


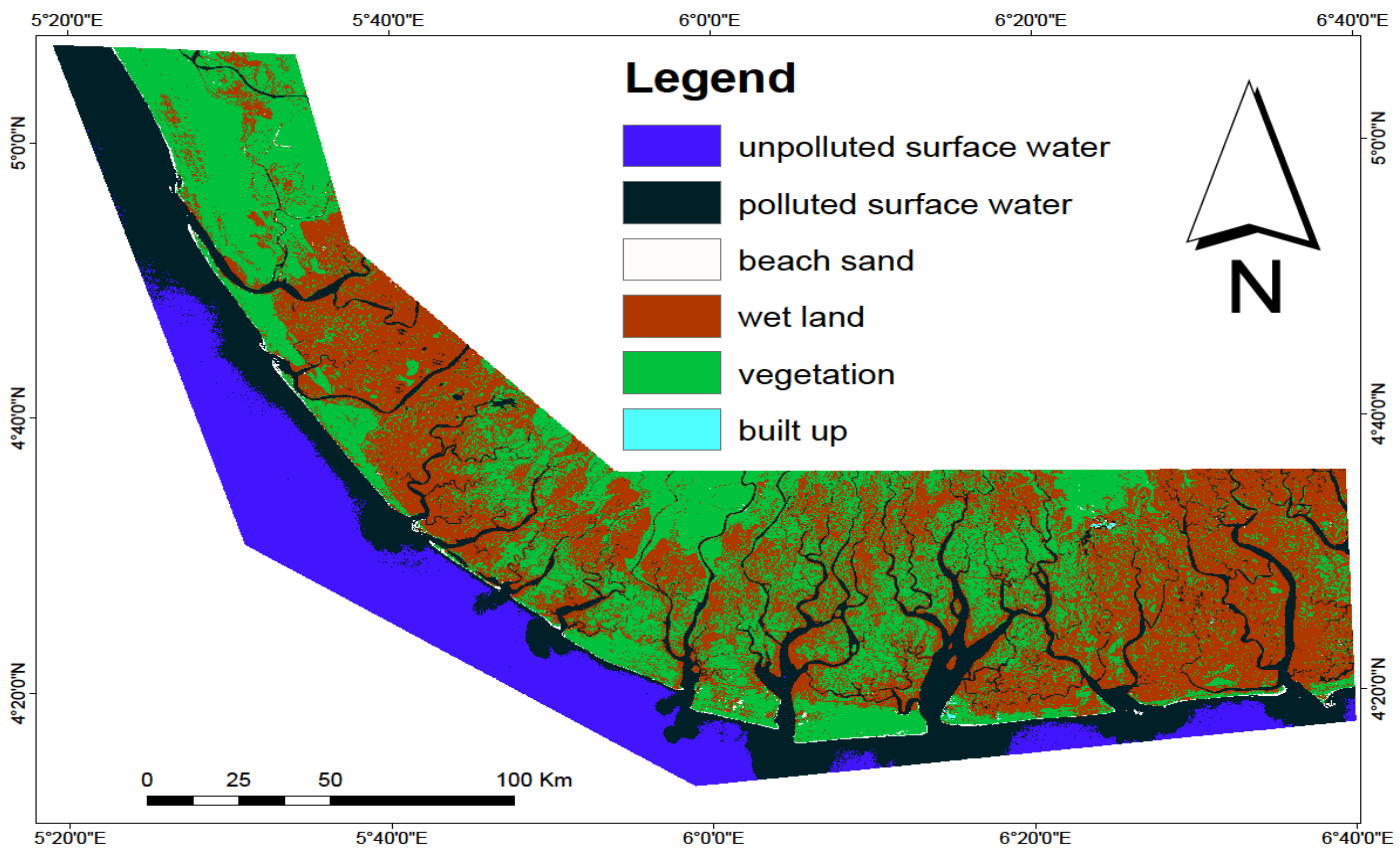

Fig. 2: Map showing the LULC for 1987 of the study area

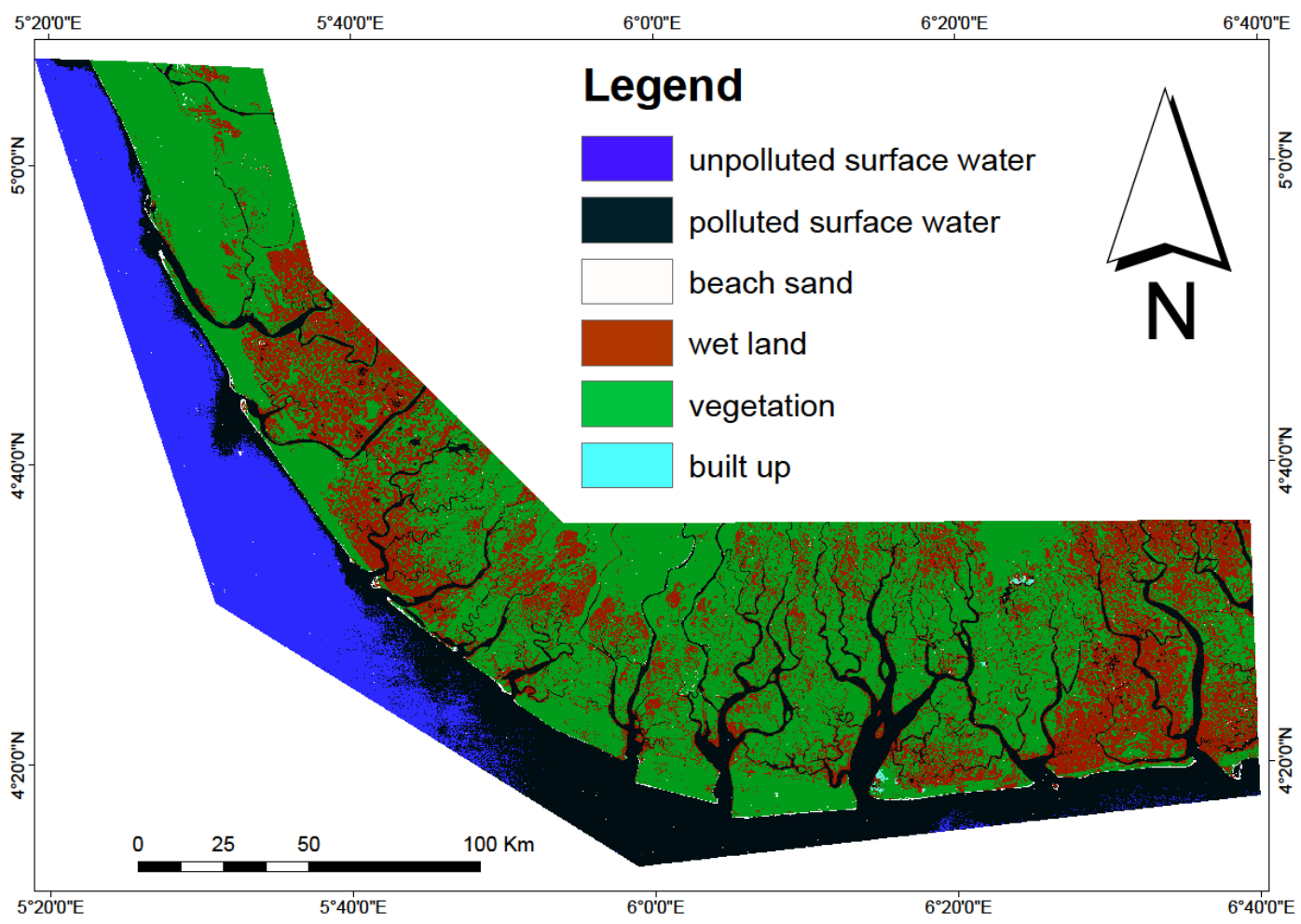

Fig. 3: Map showing the LULC for 1992 of the study area. 


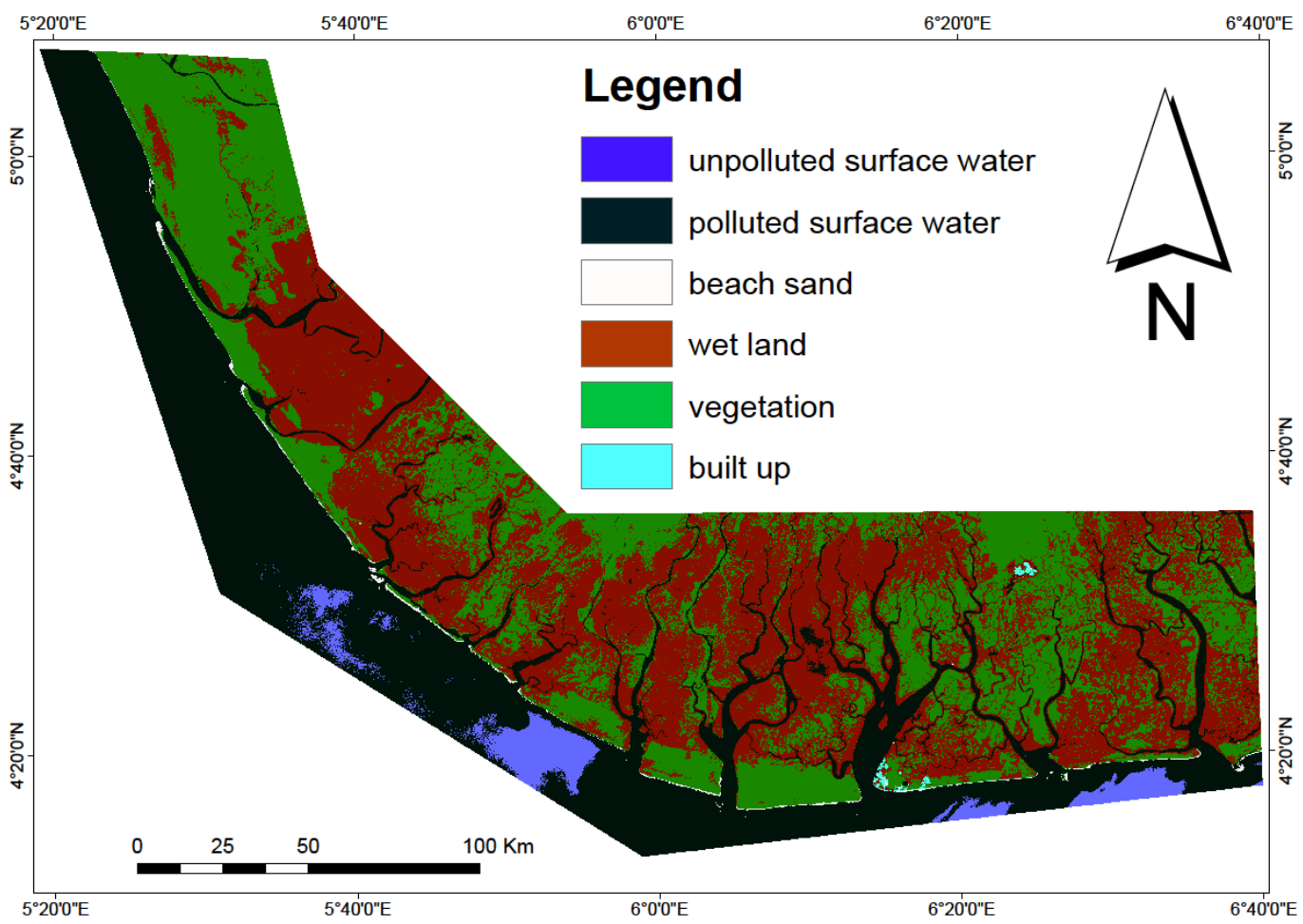

Fig. 4: Map showing the LULC for 2010 of the study area

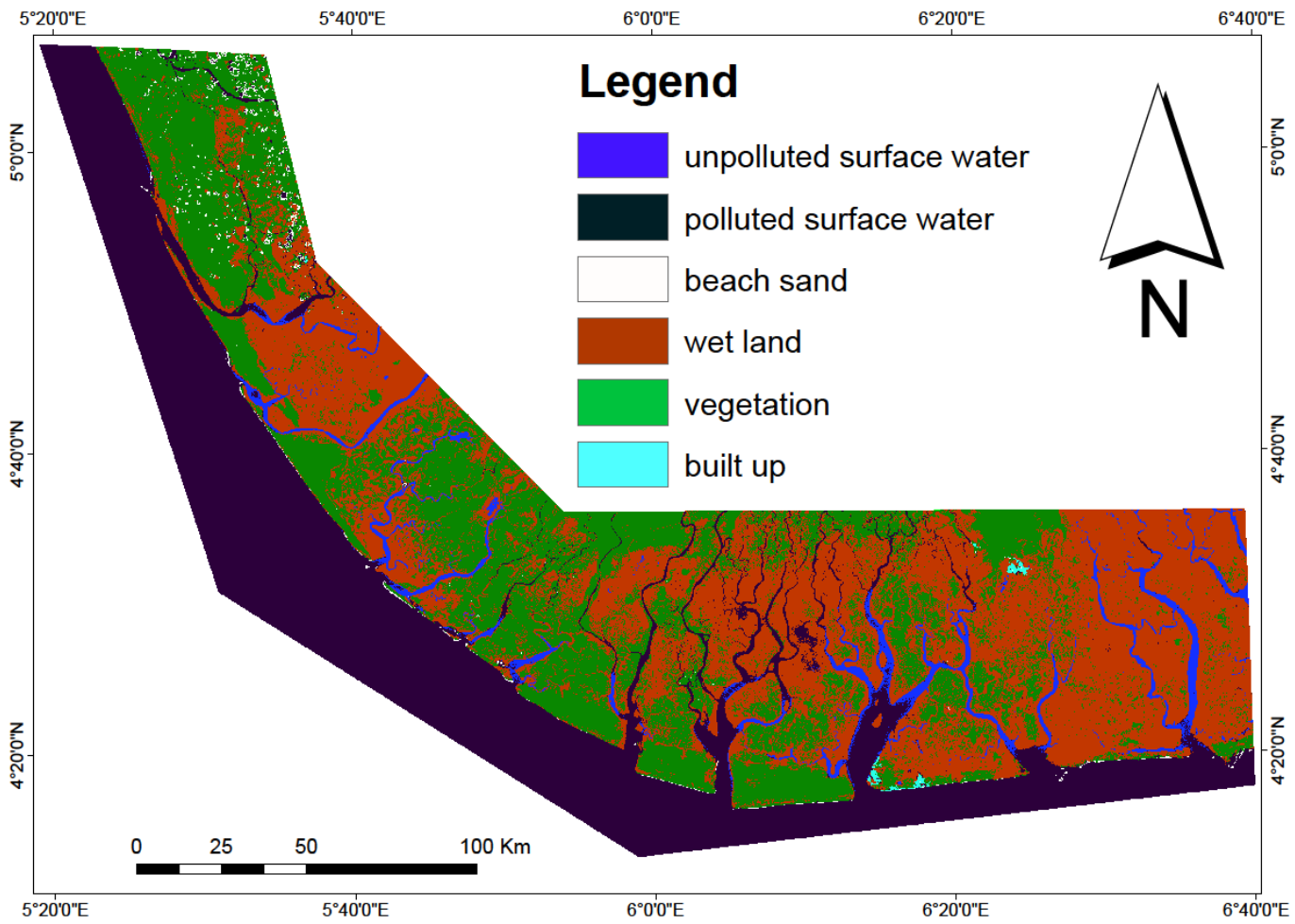

Fig. 5: Map showing the LULC for 2016 of the study area 
From the classified images, (Table 1) the built up area increased from $0.03 \%$ in 1987 to $0.05 \%$ in 1992 to $0.11 \%$ in 2010 and 2016 with the vegetated area decreasing throughout the time series from $30.47 \%$ to $30.40 \%$ and $30.36 \%$ to $28.01 \%$ respectively. The wetland area reduced within the time series from $34.83 \%$ to $34.69 \%$ and increased from $35.47 \%$ to $36.98 \%$ in 2016 . The beach sand reduced from $0.44 \%$ to $0.37 \%$ which indicates that this period underwent erosion and the increase of beach sand to $0.48 \%$ was due to accretion in 2016, as indicated in Table 1. The total area covered by water body increased between 1987 and 1992 from $31.23 \%$ to $34.44 \%$ reducing to $33.69 \%$ in 2010 and increasing further to $34.41 \%$ in 2016 . The increase and decrease in surface water body can be an indication of erosion and accretion in the study area.

Table 1: Time series analysis of landuse/landcover change

\begin{tabular}{|c|c|c|c|c|c|c|c|c|}
\hline & 1987 & & 1992 & & 2010 & & 2016 & \\
\hline NAME & $\begin{array}{l}\text { Area } \\
\left(\mathrm{m}^{2}\right)\end{array}$ & $\begin{array}{l}\text { Percent } \\
(\%)\end{array}$ & Area $\left(\mathrm{m}^{2}\right)$ & $\begin{array}{l}\text { Percent } \\
\text { (\%) }\end{array}$ & Area $\left(\mathrm{m}^{2}\right)$ & $\begin{array}{l}\text { Percent } \\
(\%)\end{array}$ & Area $\left(\mathrm{m}^{2}\right)$ & $\begin{array}{l}\text { Percent } \\
(\%)\end{array}$ \\
\hline $\begin{array}{l}\text { Unpolluted } \\
\text { Surface } \\
\text { water }\end{array}$ & 910817100 & 15.13 & 848996100 & 14.10 & 162537564 & 2.70 & 1878976800 & 31.20 \\
\hline $\begin{array}{l}\text { Polluted } \\
\text { Surface } \\
\text { water }\end{array}$ & 114997140 & 19.10 & $\begin{array}{l}122489100 \\
0\end{array}$ & 20.34 & 1865891632 & 30.99 & 193141800 & 3.21 \\
\hline $\begin{array}{l}\text { Beach } \\
\text { sand }\end{array}$ & 26232300 & 0.44 & 24601500 & 0.41 & 22163812 & 0.37 & 28742400 & 0.48 \\
\hline Wet land & 209681460 & 34.83 & 121398400 & 34.69 & 2135825692 & 35.47 & 2226947400 & 36.98 \\
\hline Vegetation & $\begin{array}{l}183450420 \\
0\end{array}$ & 30.47 & $\begin{array}{l}270589770 \\
0\end{array}$ & 30.40 & 1827807608 & 30.36 & 1686725100 & 28.01 \\
\hline Built up & 2099700 & 0.03 & 3291300 & 0.05 & 6716952 & 0.11 & 688600 & 0.11 \\
\hline
\end{tabular}

The total length of the extracted shoreline of 1987 Landsat image is $179773.78 \mathrm{~m}$, for year 1992 is $179367.44 \mathrm{~m}$, for year 2010 is $179137.19 \mathrm{~m}$, and for year 2016 is $183771.93 \mathrm{~m}$. The shorelines are represented with different colours in figure 6 . A closer look at the digitized shorelines showed that there is a remarkable change in the shape of the shoreline over time as indicated in figure 7 . The result of the analysis revealed changes in the Bayelsa shoreline, the net change measured as the distance between the most recent and earliest shorelines (1987, 1992, 2010 and 2016). The sum total of the magnitude of net erosion that occurred during the different periods under investigation is shown in the Table 2. 
Ethiopian Journal of Environmental Studies and Management Vol. 10 no.5 2017

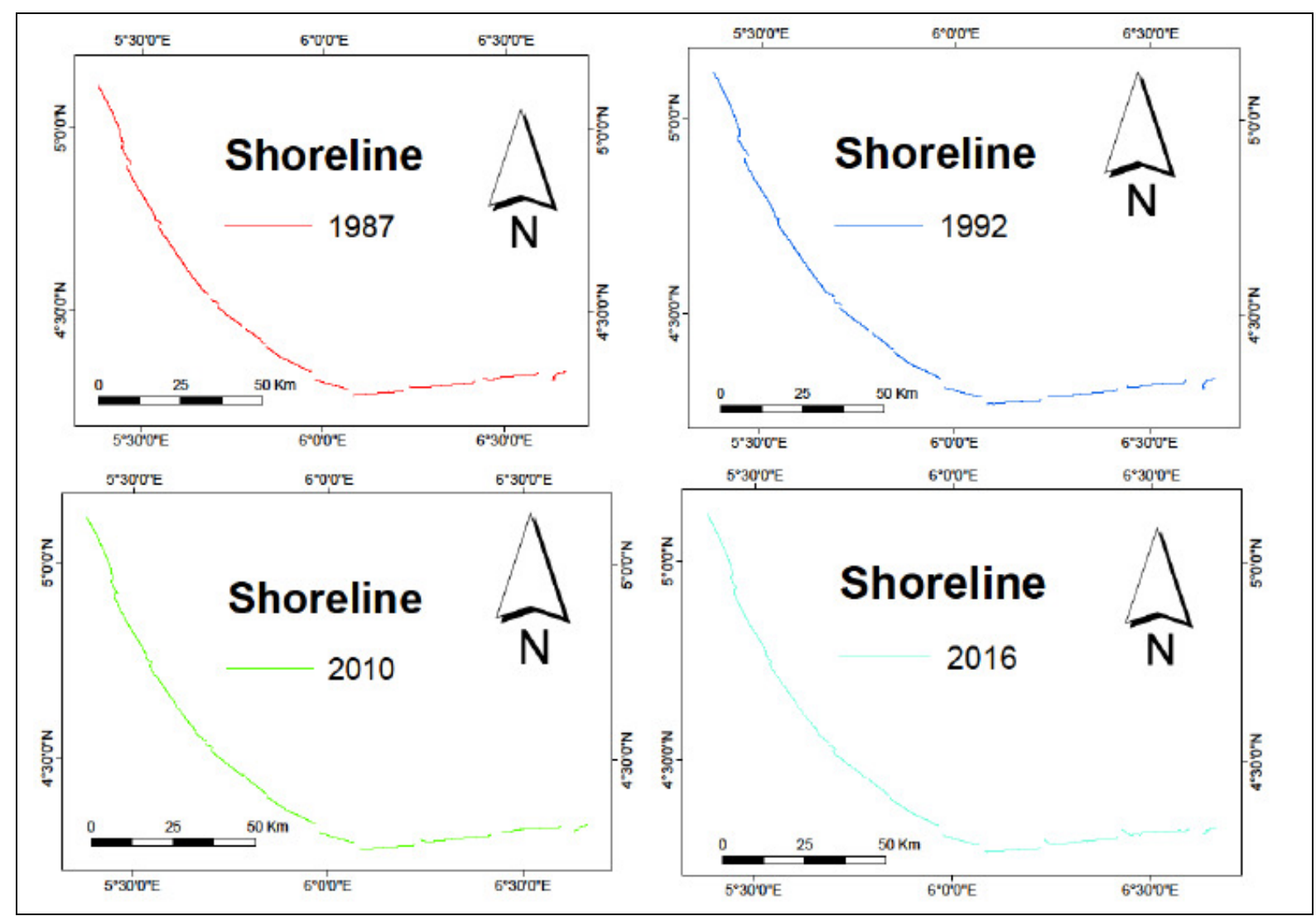

Fig. 6: Map showing the shorelines of each year of the study area 


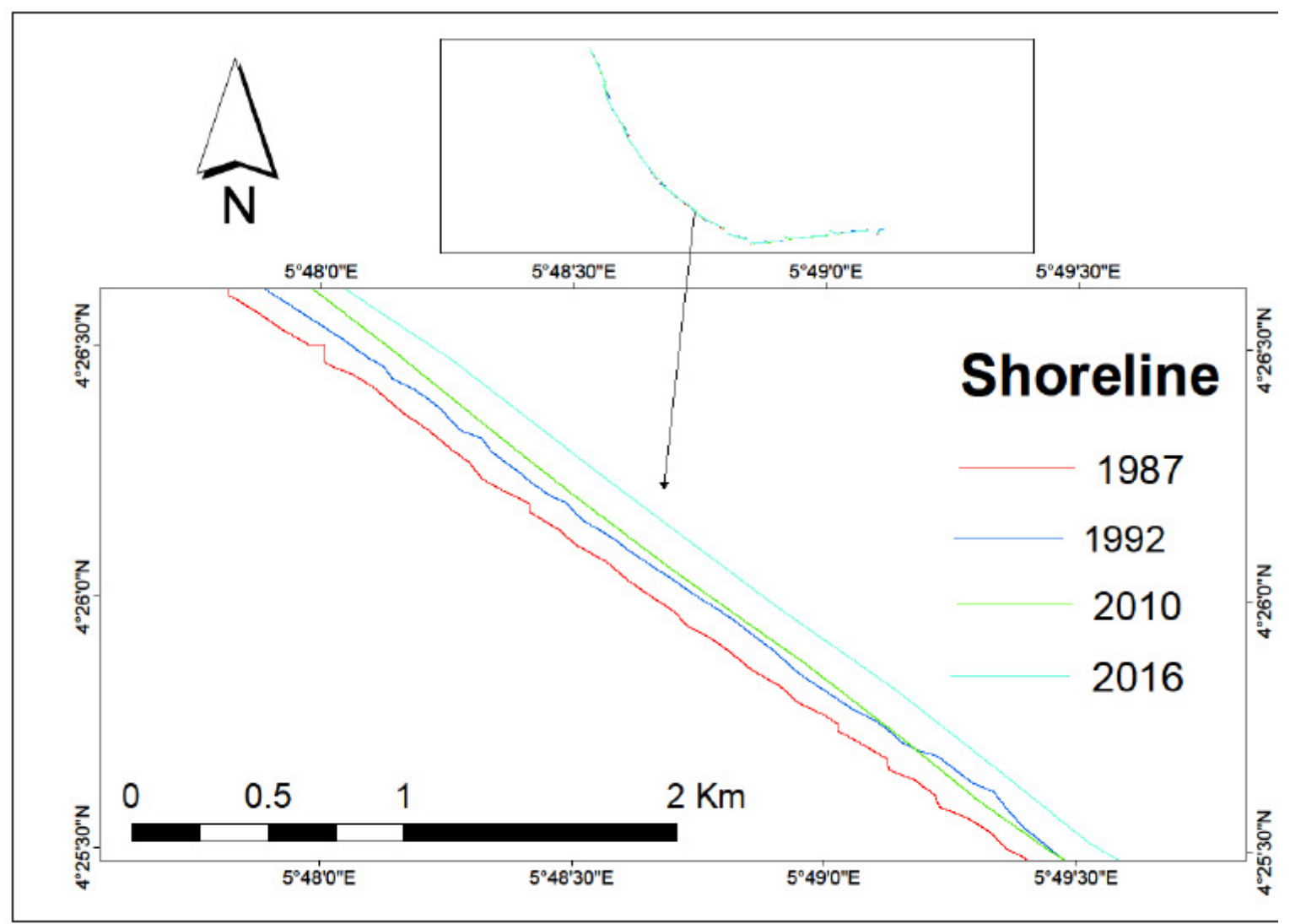

Fig. 7: Map showing the shoreline changes of the study area.

Table 2: Erosion and Accretion Rate

\begin{tabular}{lllll}
\hline Periods & Erosion & Accretion & Net Change & Annual Rate of Erosion \\
\hline $1987-1992$ & $-1940.98 \mathrm{~m}$ & $9334.1 \mathrm{~m}$ & $-7393.12 \mathrm{~m}$ & $-465.52 \mathrm{~m}$ \\
$1992-2010$ & $-17559.74 \mathrm{~m}$ & $3583.98 \mathrm{~m}$ & $13975.76 \mathrm{~m}$ & $-676.5 \mathrm{~m}$ \\
$2010-2016$ & $-3233.69 \mathrm{~m}$ & $7574.45 \mathrm{~m}$ & $-4340.76 \mathrm{~m}$ & $-650.65 \mathrm{~m}$ \\
$1987-2016$ & $-12465.89 \mathrm{~m}$ & $10191.41 \mathrm{~m}$ & $2274.48 \mathrm{~m}$ & $-365.12 \mathrm{~m}$ \\
\hline
\end{tabular}

To compute the shoreline rate of change, that is, the rate at which the coastline is eroding/ accreting; the End Point Rate (EPR) method was used. From the result generated by DSAS in the rate of change analysis result, the rate of erosion in the year $1987-1992$ is $465.52 \mathrm{~m} / \mathrm{yr}, 1992-2010$ is $-676.5 \mathrm{~m} / \mathrm{yr}$, $2010-2016$ is $-650.65 \mathrm{~m} / \mathrm{yr}$ while $1987-$ 2016 is $-365.12 \mathrm{~m} / \mathrm{yr}$, Table 2. 


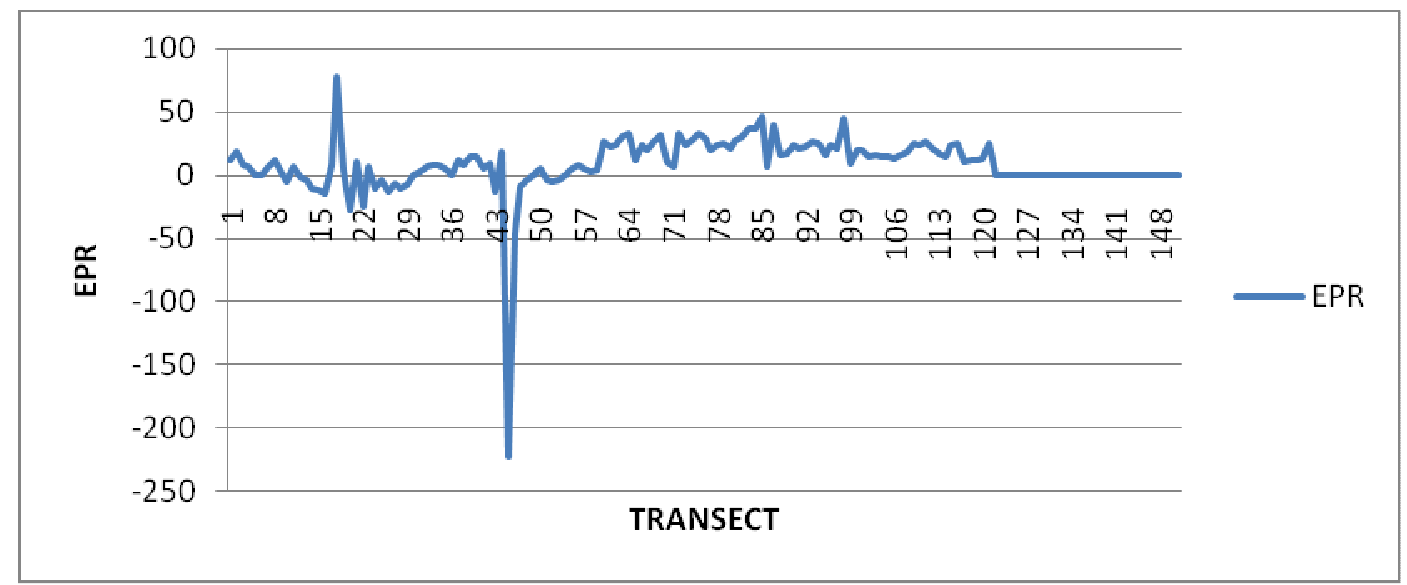

Fig. 8a: EPR of the shoreline 1987 - 1992

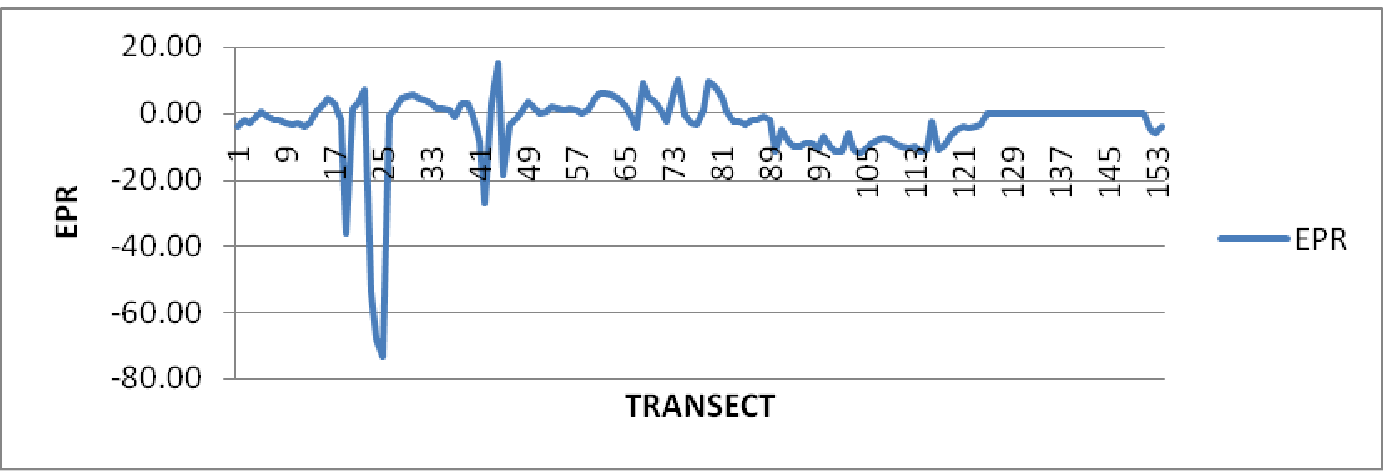

Fig. 8b: EPR of the shoreline 1992 - 2010

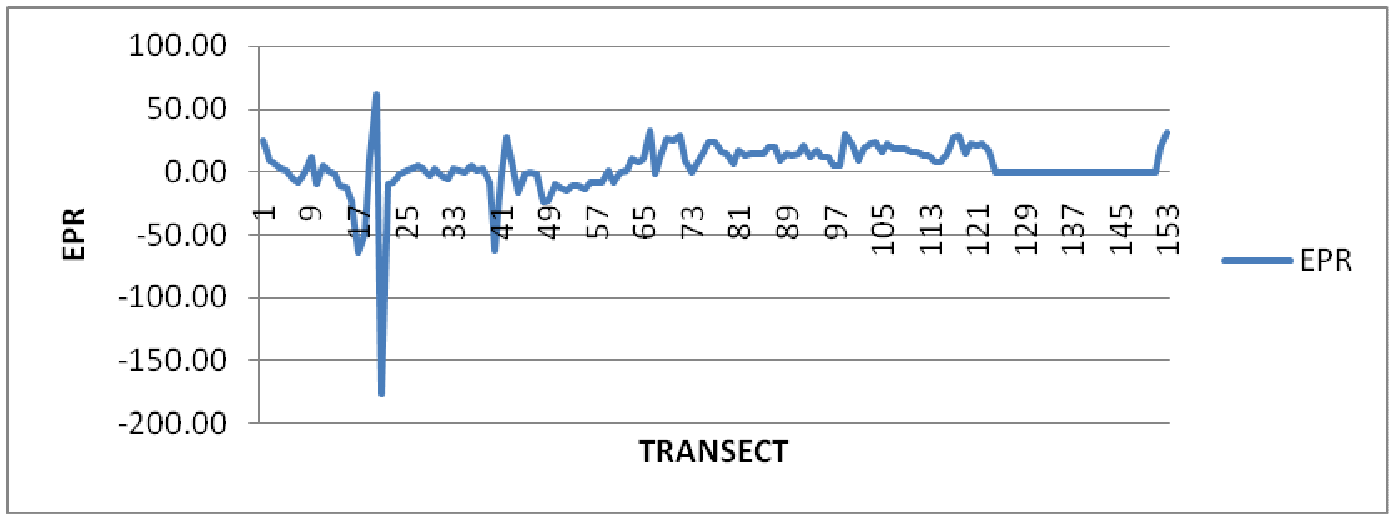

Fig. 8c: EPR of the shoreline 2010 - 2016 
Remote Sensing and GIS Applications in Determining...............ADEBOLA et al.

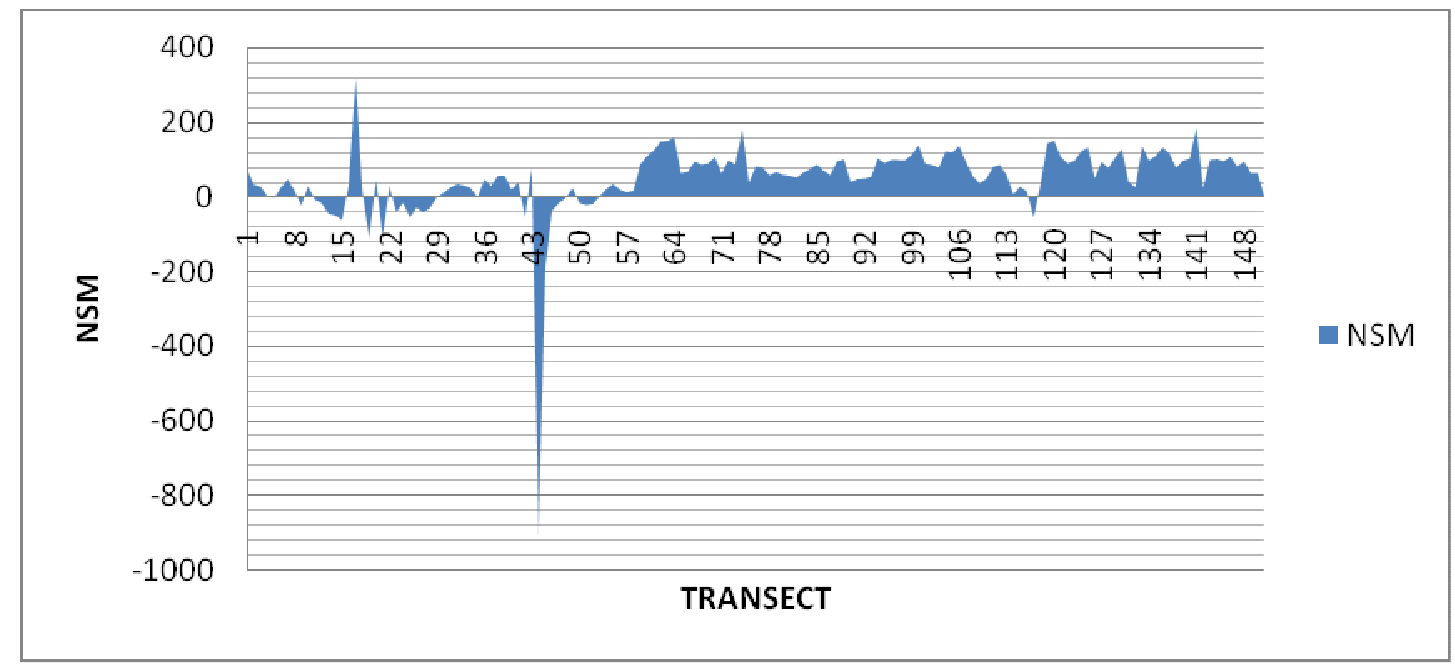

Fig. 9: Net Shoreline Movement 1987 - 1992

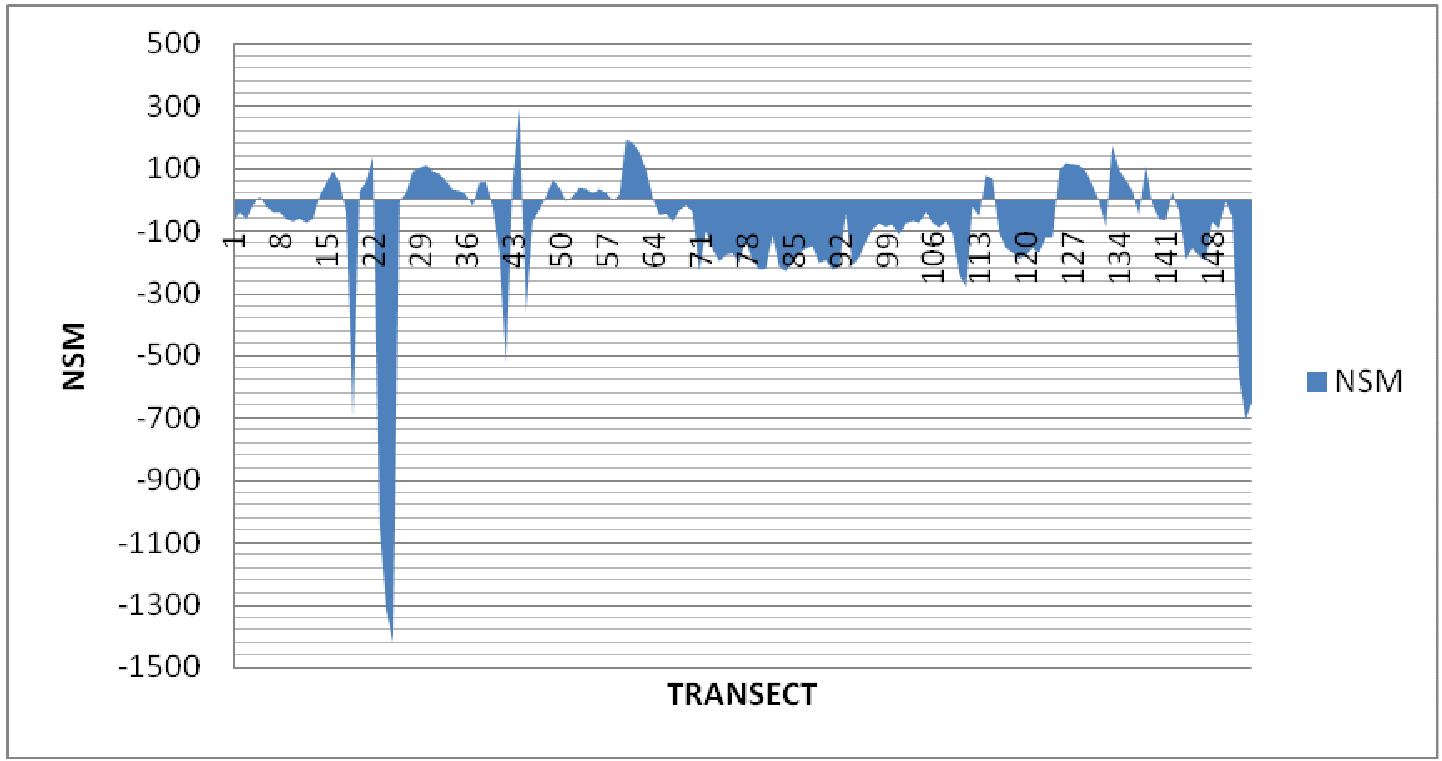

Fig. 10: Net Shoreline Movement 1992 - 2011 


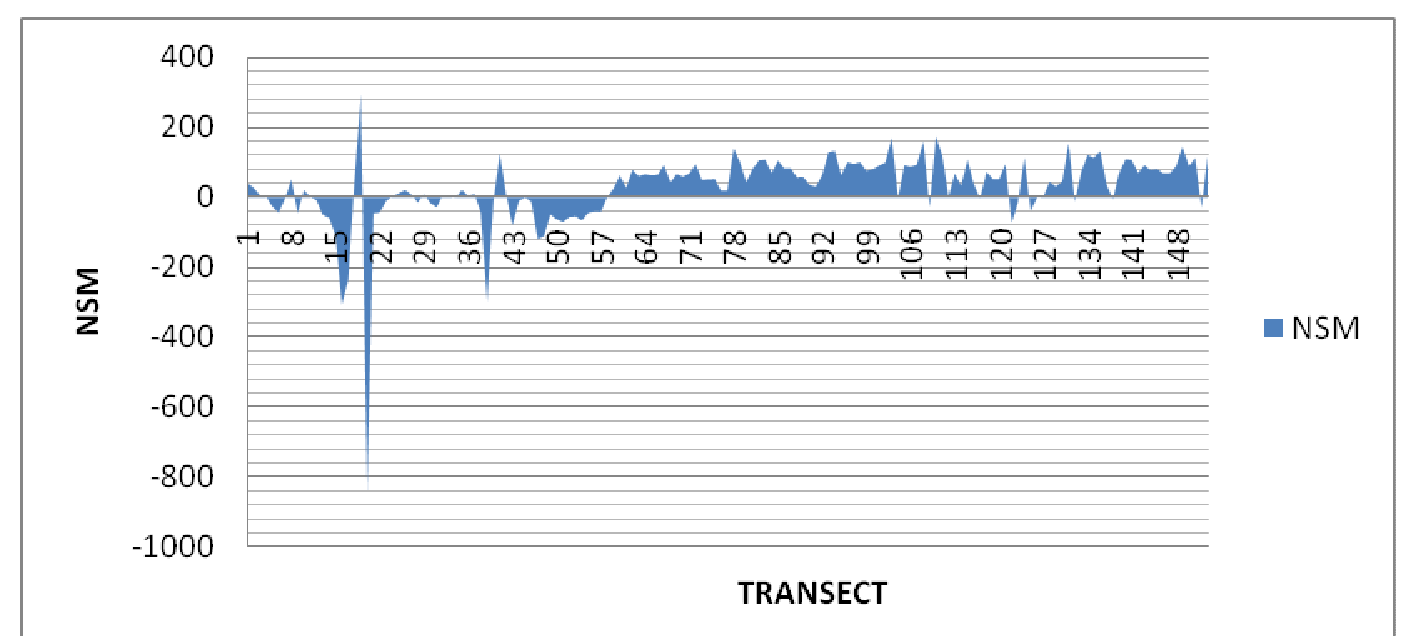

Fig. 11: Net Shoreline Movement 2011 - 2016

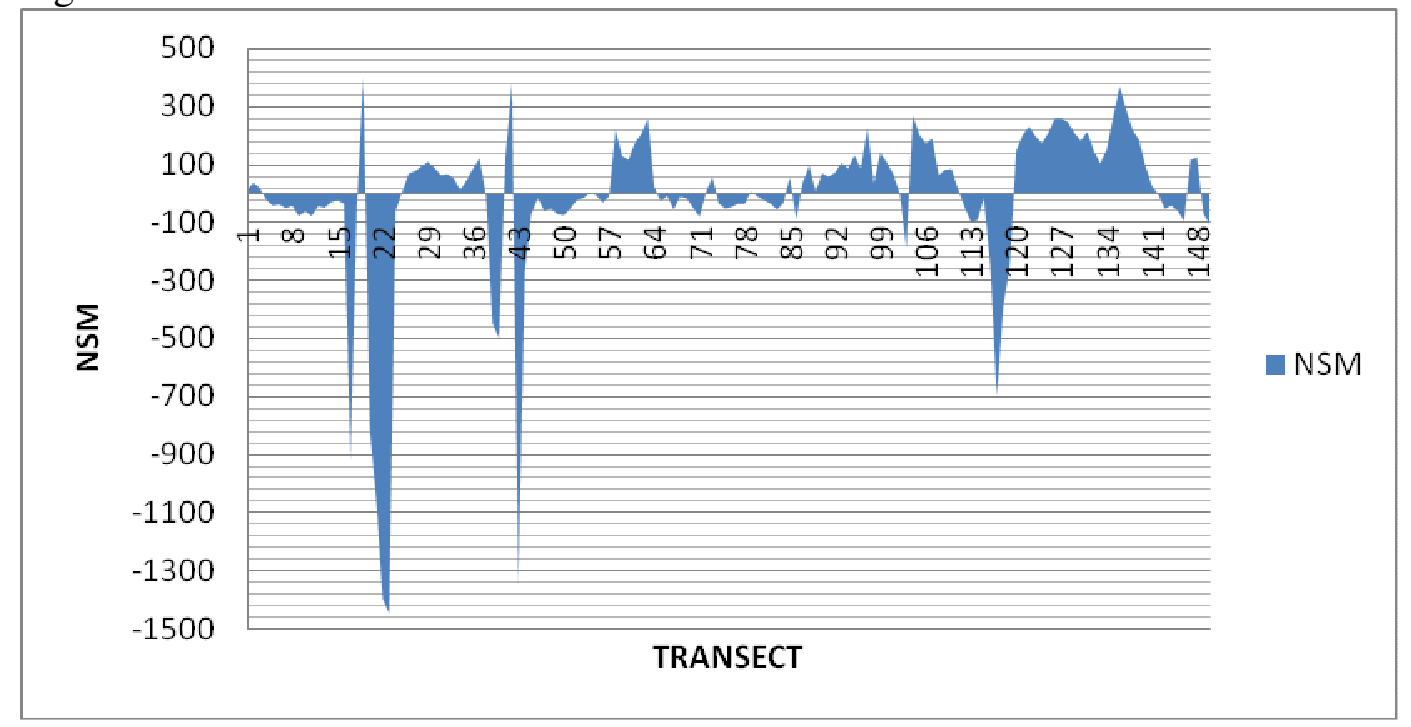

Fig. 12: Net Shoreline Movement 1987 - 2016

\section{Conclusion}

Remote sensing and GIS technique has proved useful from time in memorial for checking out the coastal environment and monitoring the changes overtime in the coastal zone. It has been observed that shoreline change in the study area results from both erosional and accretion processes. The study has revealed that erosion level in the area is more than accretion during the period studied (1987 - 2016). However, the limitation in this study is the spatial resolution of the satellite imagery used. Therefore, to further enhance the study, high-resolution images of selected sites should be used to increase the accuracy of measurements of coastline changes. Nonetheless, this study has been able to ascertain that through satellite remote sensing and GIS techniques, the Nigerian coastline can adequately be monitored for various changes that take place. 


\section{References}

Ako, B.D. (1982). Geophysical prospecting for groundwater in an area without adequate geological data base. J. Min. Geology, 18: 88105.

Areola, O. (1977). Aerial photo interpretation of land types and terrain conditions in the Lagos coastal region. Nig. Geographical Journal, 20: 70 - 81 .

Allen, J. (1965). Coastal geomorphology in eastern Nigeria: Beach-ridge barrier islands and vegetated tidal flats. Geologie en Mijnbouw. V., 44: $1-21$

Boak, E.H. and., Turner. I.L. (2005). Shoreline definition and detection: A review. Journal of Coastal Research, 21(4), 688-703.

Carter, R.W.G. and Woodroffe, C.D. (1994). Coastal evolution: Late quaternary shoreline Morphodynamics. Cambridge: Cambridge University Press, 517p

Cowell, P.J. and Thom, B.G. (1994). Morphodynamics of coastal evolution. In: Carter, R.W.G. and Woodroffe, C.D. (eds.), Coastal Evolution. Cambridge: Cambridge University Press, p. 33-86.

Dolan, R., Hayden, B.P. May, P. and May, S.K. (1980). The reliability of shoreline change Measurements from aerial photographs. Shore and Beach, 48(4): 22-29.

Di, K., Ma, R. and Li, R. (2003). Rational Functions and Potential for Rigorous Sensor Model Recovery. Photogrammetric Engineering and Remote Sensing Journal, 69(1): 3341.

Dolan, R., Fenster, M. and Holme, S.J. (1991). Temporal Analysis of
Shoreline Recession and Accretion. Journal of Costal Research, 723744.

Ebisemiju, F.S. (1986). Human impact on marine processes in the western Niger Delta. In P.O. Sada and P. O. Odemerho (eds.) Environmental Issues and Management in Nigerian Development, pp. 239 - 251

Efe Recep and Tagil, Sermin (2001). The Use of Multi-Temporal and Multispectral Landsat Data to Determine Change Detection around Tuz Lake on Seyhan Delta, Fresenius Environmental Bulletin Parlar Scientific Publications.

Ekine, A.S. and Osobonye, G.T. (1996). Surface Geo-electric sounding for the determination of Aquifer characteristics in parts of Bonny Local Government Area of River State. Nigeria. Journal of Physics, 85: 93-97.

El-Amsar, H.M. (2002). Short term coastal changes along DamiettePort said coast northeast of the Nile Delta, Egypt. Journal of Coastal Research, 18(3): 433-441

El-Raey, M., Sharaf El-Din, S.H., Khafagy, A.A. and Abo, A.I. (1997). Remote sensing of beach erosion/accretion patterns along Damietta - Port Said shoreline, Egypt. International Journal of Remote Sensing, ISSN 0143-116

Eludoyin, O.S., Okocha, C.C and Ayolagha, G. (2011) GIS Assessment of Land Use and Land Cover Changes in Obio/Akpor L.G. A, River State, Nigeria, Research Journal of Environmental and Earth Sciences, 3(4): 307-313

Ekine, A.S. and Osobonye, G.T. (1996). Surface geo-electric sounding for 
the determination Of Aquifer characteristics in parts of Bonny Local Government Area of Rivers State. Niger. J. Phys., 85: 93-97.

Fletcher, C., Rooney J., Barbee, M., Lim S. and Richmond B. (2003). Mapping Shoreline Change Using Digital Orthophotogrammetry on Maumi, Hawaii. Journal of Coastal Research, (38): 106-124.

Galgano, F.A. and Douglas, B.C. (2000). Shoreline Position Prediction: Methods And Errors, Environmental Geosciences Journal, 7(1): 23-31.

Ibe, A.C. and Antia, E.E. (1983). A preliminary assessment of the impact of erosion along the Nigerian shoreline, NIOMR Tech. Paper No. 13, 19p.

Ibe, C.A. (1985). Harbour Development Related Erosion at Victoria Island, Lagos. Paper Presented at the First Kleinbaum Conference

Kadib, A.A. (1969). Sand movement along a portion of the northern coast of United Arab Republic. $22^{\text {nd }}$ International Navigation Congress, Section 2, pp. 273-287

Li, R., Di, K. and Ma, R. (2001). A Comparative Study of Shoreline Mapping Techniques. CRC Press, pp.27-34.

Liu, H. and Jesek, K.C. (2004). Automated Extraction of Coastline from Satellite Imagery by Integrating Canny Edge Detection and Locally Adaptive Threshold Methods, International Journal of Remote Sensing, (25): 937-958.

Liu, J.K. (1998). Developing Geographic Information System Applications in Analysis of Responses to Lake Erie Shoreline Changes, M. Sc. Thesis
(Published), Ohio State University, p.119.

Michalis , L., Nektarios C., and Yiannis K. (2009). Shoreline Extraction Using Satelite Imagery, Beach Erosion Monitoring Journal, 81-89.

Moore, L. J. (2000). Shoreline mapping techniques, Journal of Coastal Research, 16(1): 111-124

NEDECO (1954). Western Niger Delta. the Hague: NEDECO. Pugh, J. C. (1953) Port Novo - Badagry Sand Ridge Complex, Research Notes, Department of Geography, University College, Ibadan, No. 3

Niger Delta Environmental Survey (NDES) (1999). Physical Environment Report on the Hydrology of the Niger Delta

Oyegoke, E.S. (1982). The invariant of waves breaking on coastal structures with venerable Slopes, Unpublished Ph.D. Thesis, University of Lagos, Nigeria

Oyegun, C.U. (1991). Spatial and Seasonal Aspects of Shoreline Changes at Forcados Beach, Nigeria. Earth Surface Processes and Landforms, 16(4): 293 - 305.

Pandian, P.K., Ramesh, S., Murthy, M.V.R., Ramachandran, S. and Thayumanavan, S. (2004). Shoreline changes and near-shore processes along Ennore Coast, East Coast of South India. Journal of Coastal Research, 20(3): 828-845

Parker, B.B. (2003). The Difficulties in Measurings Consistently Defined Shoreline. Journal of Coastal Research, (38): 44-56.

Pidwirny, M. (2006). Fundamentals of physical geography, Chapter 10: Introduction to the Lithosphere: Erosion and deposition, University 
Remote Sensing and GIS Applications in Determining...............ADEBOLA et al.

of British Columbia, Okanagan. [Online]available:http://www.physi calgeography.net/fundamentals/10w .html. Assessed: March, 2007.

Pugh, J.C. (1954). A classification of the Nigerian coastline, Journal of West African Science Association, 1: 322.

Robertson, W., Whitman, D., Zhang, K. and Leatherman, S.P. (2004). Mapping shoreline Position using airborne laser altimetry, Journal of Coastal Research. 20(3): 884-892.

Ryuet, J. (2002). Waterline extraction from landsat TM data in tidal flat a case study in Gomso bay, Korea. Remote sensing of Environment, 83(3): 442-456.

Tardie, P.S. and Congalton, R.G. (2002). A change-detection analysis: Using Remotely Sensed Data to Assess the Progression of Development in Essex County, Massachusetts from 1990-2001. Proceedings of ACSM/ASPRS Annual Conference, Retrieved from

http://www.unh.edu/naturalresources/pdf/ tardie

Usoroh, E.J. (1971). Recent rates of shoreline retreat at Victoria beach, Lagos. Nigerian Geographical Journal, 14(1): 49 - 58.

Vedast, M., Rose, S. and Charles, M. (2004). Monitoring Shoreline
Change using Remote Sensing and GIS: A Case Study of Kunduchi Area, Tanzania, Western Indian Ocean Journal of Marine Science, 3(1): 1-10.

Wang, K.D.J., Ma, R. and Li, R. (2003). Automatic shoreline extraction from high resolution Ikonos satellite imagery. In: Proceedings of the ASPRS annual Conference. Anchorage.

Woodroffe, A. (2002). Coast form, process and evolution, Cambridge University press, UK.

Webb, J.E. (1958). The Ecology of Lagos Lagoon: the Lagoons of Guinea Coast. Philosophical Transactions of the Royal Society, Series B, 683 (241): $307-317$.

Webb, J.E. (1960). The erosion of Victoria Beach, its causes and cure. Ibadan: Ibadan University Press.

Yamano, H., Matsunaga, T., Ishoda, A., Caleb, M., Hiromune, Y., Kazuhiko, F., Yoko, O. and Hajime, K. (2006). Evaluation of various satellite sensors for waterline extraction in a coral reef environment: Majuro Atoll, Marshall Islands. Geomorphology, 82(3 \& 4): 398-411. 